\title{
Kantian Themes in Ethics and International Relations ${ }^{1}$
}

\author{
Matthew Lindauer \\ Brooklyn College, City University of New York \\ In The Routledge Handbook of Ethics and International Relations, \\ eds. B. Steele and E. Heinze, New York: Routledge Press, 2018, 30-42.
}

\section{Introduction}

Immanuel Kant's writings on international relations have been extremely influential, spurring the development of idealism, ${ }^{2}$ democratic peace theory, ${ }^{3}$ and other important traditions in the field. There is something of a disconnect, however, between moral and political philosophy in what is a recognizably Kantian tradition and Kant's mark on the field of international relations. As a result, the strength of the Kantian tradition in international relations and the resources available to theories within this tradition have yet to be fully appreciated.

\footnotetext{
${ }^{1}$ I am grateful to Joy Gordon, Serene Khader, and Shmuel Nili for helpful discussion on the points raised in this chapter.

2 Pitman Potter, An Introduction to the Study of International Organization (New York: The Century Company, 1925); James T. Shotwell, "Plans and Protocols to End War," International Conciliation 208 (1925); Philip Noel-Baker, The League of Nations at Work (London: Nisbet, 1926); Alfred Zimmern, The League of Nations and the Rule of Law, 1918-1935 (London: Macmillan, 1936); Hedley Bull, The Anarchical Society: A Study of Order in World Politics (New York: Columbia University Press, 1977); Peter Wilson, "Idealism in International Relations," in Encyclopedia of Power, ed. Keith Dowding (Thousand Oaks: Sage Publications, 2011), 332-333.

${ }^{3}$ Michael W. Doyle, "Kant, Liberal Legacies, and Foreign Affairs," Philosophy and Public Affairs, 12, no. 3 (1983a): 205-235; Michael W. Doyle, "Kant, Liberal Legacies, and Foreign Affairs," Philosophy and Public Affairs, 12, no. 4 (1983b): 323-353; Andrew Hurrell, "Kant and the Kantian Paradigm in International Relations," Review of International Studies 16, no. 3 (1990): 183-205; Steven Pinker, The Better Angels of Our Nature: Why Violence Has Declined (New York, NY: Viking Books, 2011); Luigi Caranti, "Kantian Peace and Liberal Peace: Three Concerns," Journal of Political Philosophy 24, no. 4 (2016): 446-469.
} 
This chapter has two modest goals relating to two interlocking themes in moral and political philosophy in the Kantian tradition. First, I will bring some of the philosophical issues raised in interpreting Kant's ethics to bear on how we think about a Kantian understanding of international relations. In particular, I will focus on Kantian constructivism ${ }^{4}$ and how a constructivist interpretation can inform an understanding of Kant's Perpetual Peace $e^{5}$ and passages in other texts that deal with international relations. Second, drawing on this constructivist account in international relations, I will examine Kant's remarks in Idea for a Universal History with a Cosmopolitan Intent ${ }^{6}$ Perpetual Peace, and The Metaphysics of Morals ${ }^{7}$ about the dependency of domestic justice on international justice. By putting these two goals of the chapter together, we can see how a Kantian view of international relations can (1) emphasize the role of morality in international relations while remaining grounded in the resolution of practical problems and (2) offer an important lesson on the requirement that problems of international and global justice be addressed because doing so is a precondition for the resolution of

\footnotetext{
${ }^{4}$ The Kantian constructivist tradition in contemporary moral and political philosophy begins with John Rawls (see especially his "Kantian Constructivism in Moral Theory," Journal of Philosophy 77, no. 9 (September 1980): 515-572). However, as I explain below, my account draws more closely from the characterization of the constructivist tradition provided by Christine Korsgaard ("Realism and Constructivism in TwentiethCentury Moral Philosophy," Journal of Philosophical Research, APA Centennial Supplement: Philosophy in America at the Turn of the Century (2003): 99-122). ${ }^{5}$ Immanuel Kant, "To Perpetual Peace: A Philosophical Sketch" in Immanuel Kant: Perpetual Peace and Other Essays, trans. Ted Humphrey (Indianapolis: Hackett Publishing Company, 1795/1983b), 107-143.

${ }^{6}$ Immanuel Kant, "Idea for a Universal History with a Cosmopolitan Intent," in Immanuel Kant: Perpetual Peace and Other Essays, trans. Ted Humphrey (Indianapolis: Hackett Publishing Company, 1784/1983a), 29-40. Hereafter "Universal History." ${ }^{7}$ Immanuel Kant, The Metaphysics of Morals, trans. Mary Gregor (Cambridge, UK: Cambridge University Press, 1797/1996).
} 
important problems of domestic justice. Each of these points provides a response to, and the second puts pressure on, realist views in international relations.

\section{Kantian Constructivism and International Relations}

I will begin with a distinction drawn by Christine Korsgaard ${ }^{8}$ between realist and constructivist approaches in moral and political philosophy. ${ }^{9}$ A strand in philosophy that finds some expression in Aristotle's views about the difference between ethics and other areas of inquiry can be put in contrast with a view more closely associated with Plato. ${ }^{10}$

For Aristotle, ethics is different from other areas of inquiry because when we examine the virtues through philosophical analysis, "the purpose of our examination is not to know what virtue is, but to become good." 11 Rather than attempting to grasp the Form of Virtue or Goodness, the study of ethics has a point for Aristotle - helping us to figure out how to live our lives in the best way. The idea of a "point" for morality is in direct contrast with the view that the study of morality is just another area of theoretical inquiry.

\footnotetext{
${ }^{8}$ Korsgaard, "Realism and Constructivism in Twentieth-Century Moral Philosophy."

${ }^{9}$ I won't discuss other uses of the term "constructivism" at any length here. There are, of course, many other ways philosophers have employed term in both ethics and political philosophy. My use of the term also should not be taken to overlap with constructivism in international relations as understood by Nicholas Onuf or Alexander Wendt's "social constructivism." See Nicholas Greenwood Onuf, World of Our Making: Rules and Rule in Social Theory and International Relations (Columbia, SC: University of South Carolina Press, 1989) and Alexander Wendt, "Anarchy is what States Make of it: the Social Construction of Power Politics," International Organization, 46, no. 2 (Spring 1992): 391-425.

${ }^{10}$ Korsgaard doesn't mention Plato in this article, but the contrast between Plato's approach to ethical thought and Aristotle's is useful here. For her discussion of Platonic realism, see Christine Korsgaard, Sources of Normativity (Cambridge, UK: Cambridge University Press, 1996), 37-48.

${ }^{11}$ Aristotle, Nicomachean Ethics, Second Edition, trans. Terence Irwin (Indianapolis: Hackett Publishing Company, 350 B.C./1999), Book II.2, 19. Aristotle adds "since otherwise the inquiry would be of no benefit to us."
} 
The question of whether or not morality has a point or purpose is the issue that Korsgaard identifies as separating constructivist and realist moral theorists.

Korsgaard holds that morality has a practical purpose. She identifies constructivism as the view that normative concepts are solutions to practical problems. In interpreting Kant's ethics, she describes him as offering the moral law, the "categorical imperative," as the solution to a problem of practical reason. An individual will that is free needs to be governed by principles - a will that operated randomly would hardly be free in the sense of being autonomous and, relatedly, self-guiding. But the presence of those principles also must not be incompatible with freedom of the will - the will must choose them for itself. The relevant principle for Kant that solves this practical problem is the categorical imperative, which tells the will to choose a law without imposing any external constraints on the will's activity. Of course, I cannot go into the details of the argument for this conclusion here. The point, rather, is that the categorical imperative is supposed to solve a practical problem, in this case the problem of practical reason. Now, it may seem that the problem of a free will requiring a principle is not the kind of practical problem that we encounter in politics. Indeed, some have doubted that it really should be thought of as a problem. ${ }^{12}$ But it is worth noting that the tradition of interpreting Kant as a constructivist, as characterized by Korsgaard, carries along the idea that normative theorizing is aimed at certain practical problems.

Korsgaard takes this same characterization of constructivism in moral and political philosophy to appropriately describe the work of John Rawls, who named the

\footnotetext{
${ }^{12}$ Sharon Street, "Coming to Terms with Contingency: Humean Constructivism about Practical Reason," in Constructivism in Practical Philosophy, eds. Jimmy Lenman and Yonatan Shemmer (Oxford: Oxford University Press, 2012).
} 
tradition. ${ }^{13}$ For Rawls, we need a conception of justice-a specification of the shared concept 'justice' - that can guide the development and reform of a democratic society. As Rawls' corpus develops over the course of further works, it becomes clear that he was increasingly concerned with the real-world practical problem that his conception was meant to solve. With the move from A Theory of Justice $e^{14}$ to "Kantian Constructivism in Moral Theory" and then to Political Liberalism, ${ }^{15}$ the practical problem becomes not merely the need for principles in a democratic society that can be implemented, that provide the ability to prioritize among competing principles and goods, and so on. The problem becomes the predicament of a liberal society in which people of diverse faiths and worldviews must coexist and finds terms of social cooperation that they can all accept for the right kind of stability, a morally acceptable stability, to be achieved. As Rawls moves into the international sphere with The Law of Peoples, he also endorses a conception of his enterprise that has a practical emphasis, emphasizing the achievement of a stable agreement on principles of international justice between liberal and non-liberal but decent societies. Conceptions of justice in both the domestic and international sphere, for Rawls, are assessed in part by their ability to solve practical problems, and do so in the right way, not merely by achieving a modus vivendi but by establishing terms of cooperation that are fully acceptable to the relevant participants agreeing upon them. Such an approach is labeled that of a "realistic Utopia," and borrowing Rousseau's

\footnotetext{
${ }^{13}$ See Rawls, "Kantian Constructivism in Moral Theory." Korsgaard takes herself to be offering an understanding of constructivism that is compatible with Rawls' Kantian constructivism, although their descriptions differ in important ways that I do not have the space to discuss here.

${ }^{14}$ John Rawls, A Theory of Justice (Cambridge MA: Harvard University Press, 1971/rev. 1999).

${ }^{15}$ John Rawls, Political Liberalism (New York: Columbia University Press, 1993).
} 
dictum, Rawls says that his theory of justice involves "men being taken as they are and laws as they might be."16

It is in this light that I want to first urge the examination of Kant's work in international relations and views concerning the normative evaluation of interactions between political societies that bear Kant's influence. I am not a Kant scholar, and for the purposes of this chapter, the relevant issue isn't whether Kant was a constructivist or a realist in ethics, ${ }^{17}$ or how pervasive any constructivist elements of his philosophy were across his works in moral and political philosophy. Rather than focusing only on ascertaining what Kant the individual might have thought, my goal here is to explore what a constructivist approach of the kind described by Korsgaard can offer to theorists working in international relations. ${ }^{18}$ This type of constructivist approach differs from

\footnotetext{
${ }^{16}$ Jean-Jacques Rousseau, The Social Contract, Or Principles of Political Right, Book I, 1762, transl. G.D. H Cole, public domain. John Rawls, The Law of Peoples (Cambridge, MA: Harvard University Press, 1999), 7.

${ }^{17}$ For realist interpretations of Kant, see Allen Wood, Kant's Ethical Thought (Cambridge, UK: Cambridge University Press, 1999) and Karl Ameriks, "On Two NonRealist Interpretations of Kant's Ethics," in Interpreting Kant's Critiques (Oxford: Oxford University Press, 2003), 263-282.

${ }^{18}$ It is not uncommon for philosophers examining or advancing Kantian themes in moral or political philosophy to separate what Kant himself thought from the Kantian tradition or even Kantian ideas. Onora O'Neill writes: "Much contemporary work on justice is seen, both by protagonists and by critics, as Kantian. Evidently not all its conclusions accord with Kant's views on obligation, rights or justice; but this in itself is not surprising since its aim is to develop Kant's basic insights, even to improve on his conclusions" (Onora O'Neill, Bounds of Justice, (Cambridge, UK: Cambridge University Press, 2000), 65). Shelly Kagan draws a distinction between "Kantianism" (what Kant himself thought) and "kantianism" (the type of approach to moral theory that Kant represents) when working on a reconciliation of Kantianism and consequentialism (Shelly Kagan, "Kantianism for Consequentialists," in Immanuel Kant, Groundwork for the Metaphysics of Morals, trans. Allen W. Wood (New Haven: Yale University Press, 2002), 111-156). Pablo Gilabert also separates Kant's own views on duties of justice and global poverty from views that bear Kant's influence (Pablo Gilabert, "Kant and the Claims of the Poor," Philosophy and Phenomenological Research, 81, no. 2 (September 2010): 382418).
} 
views that are currently described as "constructivist" in international relations, ${ }^{19}$ which tend to emphasize the ways in which important aspects of relations between states are constructed through ongoing practices and interactions. However, my view is that the Kantian constructivist approach characterized by Korsgaard is importantly absent from existing debates in international relations, and this label is worth retaining when entering into such debates for reasons of continuity with the philosophical literature.

Why adopt this approach? First, doing so has the potential to unseat some assumptions about Kantian theories that tend to support the kinds of objections typically raised by realists in international relations. Realists are skeptical about the role that morality can play in international relations. ${ }^{20}$ While this skepticism takes different forms for different theorists in the realist tradition, ${ }^{21}$ realism is typically contrasted with "idealism," of which Kant is thought of as a key progenitor. As noted by Peter Wilson, ${ }^{22}$ idealism is generally characterized as the perspective on international relations that emphasizes the role of international norms, interdependence, and cooperation among states. ${ }^{23}$ Further, the term 'idealism' is often employed by realists in a rhetorical way,

${ }^{19}$ Onuf, World of Our Making: Rules and Rule in Social Theory and International Relations and Wendt, "Anarchy is what States Make of it: the Social Construction of Power Politics."

${ }^{20}$ W. Julian Korab-Karpowicz, "Political Realism in International Relations," in The Stanford Encyclopedia of Philosophy, Summer 2013 Edition, ed. Edward N. Zalta, URL $=<$ https://plato.stanford.edu/archives/sum2013/entries/realism-intl-relations $/>$.

${ }^{21}$ See, e.g., Hans J. Morgenthau, Scientific Man Versus Power Politics (Chicago: Chicago University Press, 1946) and Kenneth Waltz, Theory of International Politics (Boston, MA: McGraw-Hill, 1979).

${ }^{22}$ Peter Wilson, "Idealism in International Relations," 332-333.

${ }^{23}$ In following Wilson's characterization of idealism, I intend for the term to apply broadly to a perspective in international relations theory, rather than being limited only to the idealist theories put forward by liberal internationalists during the interwar period (see, e.g., Potter, An Introduction to the Study of International Organization; Shotwell, "Plans and Protocols to End War;" Noel-Baker, The League of Nations at Work; and 
with the purpose of discrediting radical or reformist ideas that they disagree with. ${ }^{24}$ For this reason, the association of Realism with realistic assessments of what interactions between states really are like and Idealism with idealistic and thereby less realistic conceptions is perhaps unavoidable.

While it is clearly true, for instance, that states are often not driven by normative principles in their interactions with other states, Kant and political philosophers working in the Kantian tradition are well aware of this. When paired with a constructivist understanding of normative concepts as solutions to practical problems, idealism can serve as a pragmatic, but still morally constrained, approach to international relations. The separation between a global scheme of relationships between states and persons governed by rules they all could reasonably accept and one that they merely accept because of their current interests and bargaining power is not one between principlebased and fact-based theories. Rather, the former involves a commitment both to practicality and moral constraints (it is questionable that the latter is practically useful, for reasons that I discuss in the next section). These moral constraints (i) inform the kind of solution that we seek for a given practical problem in international relations (not one inconsistent with plausibly moral values), (ii) set a moral goal for the task of doing philosophical work on these questions, that is, helping to solve practical problems, and (iii) provide reasons to revise our conceptions insofar as they cease to satisfy requirements (i) and (ii).

Zimmern, The League of Nations and the Rule of Law, 1918-1935. I am grateful to Eric Heinze and Brent Steele for suggesting that I clarify this point.

${ }^{24}$ Ibid., 331. 
Notably, many of Kant's remarks on international relations support the claim that he has practical constraints in mind when he offers at least some of his views on international relations. His objections to the possibility of world government, for instance, are empirically grounded and based on assessments of what would actually occur in the real world. If "laws invariably lose their impact with the expansion of their domain of governance," 25 a world government could not effectively legislate. Kant adds that a world government would be a "soulless despotism" bound to devolve into anarchy. ${ }^{26}$ In place of a world state, the "negative surrogate" of an enduring and expanding federation must be introduced to solve the problem of international relations.

While Kant offers somewhat different conceptions of what would suffice as an appropriate arrangement of international power across his works, these conceptions are also, in part, tailored to empirical conditions that societies actually face when interacting with one another. Indeed, many of the articles of perpetual peace, which provide the blueprint for Kant's foedus pacificum, are justified on the basis of practical considerations. ${ }^{27}$ Standing armies should be gradually abolished (Preliminary Article 3 ) not because they are morally wrong in themselves but because they threaten other nations with the appearance of being ready for war, producing arms races that become more costly for states than going to war itself. National debts in the service of foreign affairs are prohibited (Preliminary Article 4) because they make it too easy for nations to amass a large war chest and jeopardize innocent nations that would be harmed by the bankruptcy of a nation that could not repay its debt. One nation interfering with the

\footnotetext{
${ }^{25}$ Kant, "To Perpetual Peace: A Philosophical Sketch," 125.

${ }^{26}$ Ibid.

${ }^{27}$ I am grateful to Joy Gordon for discussion on this point.
} 
constitution and government of another is prohibited (Preliminary Article 5), except in some circumstances where there is an internal conflict in it, not only because doing so violates the rights of an independent people, but also because it "renders the autonomy of every nation insecure." ${ }^{28}$ Similarly practical reasons are given in favor of the sixth Preliminary Article, which prohibits acts of war that "shall make mutual trust impossible during some future time of peace." ${ }^{29}$ Kant refers to the use of assassins or poisoners, breach of surrender, and the instigation of treason in an opposing nation as "intrinsically despicable," but doesn't stop there. He states that once these means of war that are mala in se are used, they "cannot long be confined to war alone." ${ }^{30}$ In virtue of carrying over into peacetime, Kant thinks these means threaten to bring about "a war of extermination" where perpetual peace would occur "only in the vast graveyard of humanity as a whole." ${ }^{31}$

In addition to the practical justifications that he gives for most of the preliminary articles of perpetual peace, Kant includes claims about practical consequences in justifying the first of his definitive articles that allow for a state of peace between nations to be actively established. Kant argues that "in addition to the purity of its origin, a purity whose sources is the pure concept of right," ${ }^{\prime 32}$ the republican mode of government is less likely than alternatives to resort to war. Kant describes republicanism as the separation of executive and legislative power - the power that executes the law is distinct from the power that decides on the law. Whereas "the easiest thing in the world to do is

\footnotetext{
${ }^{28}$ Ibid., 109.

${ }^{29}$ Ibid., 109-110.

${ }^{30}$ Ibid., 110.

${ }^{31}$ Ibid.

${ }^{32}$ Ibid., 113.
} 
to declare war" when a ruler is not a fellow citizen, citizens who bear the costs of war, including fighting the war themselves, will be very cautious about deciding to enter into it. It is because citizens and not a ruler or rulers decide on laws to be enacted, including decisions to go to war, that Kant believes a republican government will tend not to resort to war. This is an important part of Kant's justification for the first definitive article's contention that every nation should have a republican civil constitution. The republican form of government is more conducive to solving the practical problem of overcoming tendencies to engage in war than other forms of government, according to Kant, and this is presented both as a strike in its favor and a reason for its presence within the first definitive article of perpetual peace.

Given these points, it is hard not to read Perpetual Peace as a work that aims to use moral concepts and principles to solve the practical problem of war. It embodies the idealist commitments to the importance of norms, interdependence, and cooperation among states while remaining practically-oriented and responsive to evidence about how individuals and states actually are.

Taking a constructivist approach to international relations also allows for a Kantian view to be flexible in light of the fact that the problems of war and achieving peace are not the only pressing problems currently facing the international order. Other threats, environmental, epidemiological, and so on, could also be part of a Kantian constructivist approach to designing international institutions that emphasizes moral considerations but takes empirical facts into account.

Solving pressing moral problems at the international level requires cooperation not only between liberal societies but also with some non-liberal societies. It is therefore 
important to note that a practically-oriented Kantian approach can embrace the Rawlsian view that non-liberal states of certain kinds must be treated as equal participants in international society. ${ }^{33}$ Michael Doyle, while generally embracing Kant's views about the importance of liberal societies to international peace, criticizes the Kantian legacy in international relations for its failures to engage constructively with nonliberal powers. ${ }^{34}$ Kant himself was not appropriately sensitive to diversity between different types of societies. While he had some qualms with colonialism, he also embraced what we now recognize as morally problematic views about the causes of differences between peoples and cultures. The requirements to work across lines of different types of political arrangements and not try to stamp political diversity at the international level are ones that contemporary philosophers working in the Kantian tradition generally accept.

Lastly, Kant's strong commitments to state sovereignty and the general impermissibility of rebellion may have changed if he had observed the changing practical circumstances that the world would face after his death. Kant never witnessed the horrors of the 20th century and the now well-recognized dangers of authoritarianism and obedience to power, dangers that arise from well-known aspects of human psychology. ${ }^{35}$ In light of the prominent dangers of state power, Kant may have come to embrace the permissibility of humanitarian intervention, as contemporary Kantian thinkers have. ${ }^{36}$ In the case of the right to rebel, Kant notably does not argue that rebellion is wrong in states

\footnotetext{
${ }^{33}$ Rawls, The Law of Peoples.

${ }^{34}$ Doyle, "Kant, Liberal Legacies, and Foreign Affairs" (1983b).

35 Stanley Milgram, "Behavioral Study of Obedience," Journal of Abnormal and Social Psychology 67, no. 4 (1963): 371-378.

${ }^{36}$ See, e.g., Carla Bagnoli, "Humanitarian Intervention as a Perfect Duty: A Kantian Argument," Nomos 47 (2004).
} 
without the right kind of domestic structure. ${ }^{37}$ We may be more or less capacious in our view of which states are ones where we should recognize or perhaps aid rebellions, in keeping with what we've learned about the risks of unchecked state power and the dangers of many humanitarian interventions. ${ }^{38}$ However, a Kantian approach need not be hostage to Kant's own views on the topics of state sovereignty or rebellion, as they are peripheral to Kant's own core commitments and not central in any way to a Kantian constructivist approach to theorizing about international relations.

\section{The Relationship Between Domestic and International Justice}

With the Kantian constructivist approach in mind, I now wish to draw the reader's attention to a passage from Kant's 1784 The Idea for a Universal History with a Cosmopolitan Intent that will be important for much of the rest of what I have to say here:

"The problem of establishing a perfect civil constitution depends on the problem of law-governed external relations among nations and cannot be solved unless the latter is." 39

In this often overlooked passage which begins the "Seventh Thesis" of Universal History, Kant seems to be suggesting that solving one problem, a problem of domestic justice, is contingent on another problem being solved, a problem of international justice. In the language of this passage itself, of course, Kant doesn't say anything about normative requirements on the shape that a solution to the international problem must take, whereas

\footnotetext{
${ }^{37}$ Arthur Ripstein, Force and Freedom: Kant's Legal and Political Philosophy (Cambridge, MA: Harvard University Press, 2009).

${ }^{38}$ Michael Walzer, Spheres of Justice: A Defense of Pluralism and Equality (New York: Basic Books, 1983).

${ }^{39}$ Kant, "Idea for a Universal History with a Cosmopolitan Intent," 34.
} 
the domestic civil constitution needing to be established is described as "perfect." But Kant clearly is not interested in a mere modus vivendi in international relations, and also recognizes the imperfection of interactions between persons in even the best liberal republics. He holds that nearly all of our rights are only fully realized within a constitutional republic, and also that perpetual peace is "the supreme political good" in the very last line of the "Doctrine of Right," the first part of The Metaphysics of Morals. ${ }^{40}$ What is the relation between the two?

In moving to this broader question, we may begin by asking in what ways the problem of securing a domestically just society can be said to be contingent on securing a law-governed, just relationship among states. While this is an interesting way of proceeding, I also want to think about this relationship as a transitive one. That is to say, certain features of human social life can only be secured by solving the problem of a domestically just state and, if we take Kant's suggestion above, securing them will also require solving the problem of a just international order. To express this formally:

Domestic Principle (DP): For certain features of human social life to be secured, the problem of a domestically just state must be solved.

International Principle (IP): For the problem of a domestically just state to be solved, the problem of a just international order must be solved.

${ }^{40}$ Kant, The Metaphysics of Morals, 6:355, 124. 
Transitivity of the Domestic and International Principle (TDIP): For certain features of human social life to be secured, the problem of a just international order must be solved.

Put this way, in terms of transitivity, the claim is more striking. In some sense, the world has never seen a fully just international order, which is part of what has led realists to posit that international relations are a state of anarchy. However, not many theorists other than thoroughgoing anarchists have been inclined to say that there have never been, even for brief periods of time, states that were just. Further, depending on which features of human social life the existence of a domestically just society is supposed to secure, it is quite a radical conclusion to say that these features have not yet been secured or cannot be insofar as the international order is not just. Rather than eschewing this more radical conclusion, however, I want to pursue it, because it strikes me that good sense can be made of it that is compatible with a Kantian perspective on international relations. Further, if TDIP holds, a problem arises for theorists who wish to view domestic relations in terms of justice and international relations in terms of anarchy, because the lawlessness of the latter jeopardizes the lawfulness of the former.

When Kant expresses what I'm calling the TDIP in Universal History, he doesn't explicitly draw the connection between this principle and the more specific aspects of his domestic justice theory. Indeed, The Metaphysics of Morals was published in 1797, thirteen years after Universal History, which also precedes the Groundwork ${ }^{41}$ by one year, although the Groundwork doesn't give sustained attention to issues of political

${ }^{41}$ Immanuel Kant, Groundwork of the Metaphysics of Morals, trans. Mary Gregor (Cambridge, UK: Cambridge University Press, 1785/1997). 
justice. Instead, Kant is providing a theory of history as driven towards the establishment of a "universal cosmopolitan state." 42 The "theses" provided in this work are propositions that are supposed to show that history is developing in this direction, and that the self-interested motives of human beings progressively give way to moral motivations and expanding, just political institutions. So far this allows us to see why a universal cosmopolitan state might be, as Kant says, "the inevitable outcome of the distress that men cause one another." ${ }^{43}$ Just as pre-political individuals eventually had to give up their unconstrained freedom and seek the calm and security of political society, societies will be led to "leave the lawless state of savagery and enter into a federation of peoples. ${ }^{\prime 4}$ But what about this makes solving the problem of a just international order necessary for the solution of the domestic problem, as opposed to an inevitable further development?

Kant states that the consequences of war and the threat of war for states are devastation, upheaval, and the "complete exhaustion of their inner powers," 45 and hence states must move towards a law-governed relationship with other states. So here we have our first interpretation of the TDIP, one that is fully compatible with the realist's skepticism about the role of morality in international relations. The stability of domestic societies, on this interpretation, depends on there being a solution to the problem of anarchy on the world stage, and the only way to get rid of this problem is to develop a law-governed relationship between states. Where a rightful civil constitution enables human tendencies, both to help others and to help ourselves, to contribute to establishing

\footnotetext{
${ }^{42}$ Kant, "Idea for a Universal History with a Cosmopolitan Intent," 38.

${ }^{43}$ Ibid., 35.

${ }^{44}$ Ibid., 34.

${ }^{45}$ Ibid.
} 
a social order in which we progress as individuals, a just international order will manage the selfish (and perhaps other-regarding) tendencies of states and support such progress. Without law-governed external relationships - relationships with other states, in this case - a domestic state is subject to the destabilizing effects of war and conflict. Hence the aspect of human social life that the domestic state makes possible, progress in line with the development of reason, is contingent upon a just international order being put in place. Such a picture is largely amoral, except insofar as we take the term 'progress' to have unavoidable moral connotations. A truly value-neutral version of this argument, of course, can be given solely in terms of the requirements for the stability of a domestic society. Except for the emphasis on progress here, there is little for realists to disagree with in their skepticism about the role of morality in international relations. Maintaining a stable international order is simply in states' interests because they wish to avoid the destabilizing effects of war and conflict.

If we pivot from Universal History to The Metaphysics of Morals, the TDIP yields a different conclusion about the dependence of domestic justice on international justice, one that centers on the political morality of property rights. Kant's view of the nature of property differs greatly from the well-known Lockean alternative, as well as those of most other deontologists. ${ }^{46}$ Obviously, it is also not a utilitarian view, which would reduce the moral significance of property rights to the contributions that property rights conventions make to overall utility. But unlike Locke, Kant doesn't take property rights, at least non-provisional property rights, to be pre-institutional. In the state of nature, prior to the establishment of a constitutional republic, Kant argues that we can

\footnotetext{
46 This discussion borrows from Arthur Ripstein's masterful treatment of these issues. See Ripstein, Force and Freedom: Kant's Legal and Political Philosophy.
} 
only acquire property provisionally. Kant states the Universal Principle of Right (UPR) as follows: "an action is right if it can coexist with everyone's freedom in accordance with a universal law, or if on its maxim the freedom of choice of each can coexist with everyone's freedom in accordance with a universal law." ${ }^{47}$ Kant holds that the UPR is a "postulate incapable of further proof," 48 although he does give arguments for the UPR and for the implications he draws from it. The UPR gives rise to the "one innate right" that we each have, which is the right to "Freedom (independence from being constrained by another's choice), insofar as it can coexist with the freedom of every other in accordance with a universal law." ${ }^{49}$ This is "the only original right belonging to every man by virtue of his humanity." ${ }^{50}$ If we think carefully about the conditions of this freedom, according to Kant, we will see that the ability to securely acquire property in ways that we recognize, which place others under obligations to regulate their conduct in relation to our property, cannot be exercised unilaterally. In the state of nature, we can provisionally acquire objects that we are in physical contact with and keep on our persons. But our ability to have a "perfected" ${ }^{51}$ right to those objects, a right that includes security of our possession of the object, a clear boundary between what is ours and what is owned by others, and the ability to coerce others who seek to use our property in ways that we do not approve, requires a public authority. The Lockean view,

\footnotetext{
${ }^{47}$ Kant, The Metaphysics of Morals, 6:230, 24.

${ }^{48} \mathrm{Ibid} .$, 6:230, 25.

${ }^{49}$ Ibid., 30.

${ }^{50}$ Ibid.

${ }^{51}$ Kant rejects the distinction between perfect and imperfect rights, but Gregor in her editor's notes (58, note 21) and Ripstein use it in describing Kant's view. Gregor attributes the distinction to Pufendorf, who used it as an emendation of Grotius' distinction between faculties and aptitudes. Perfected rights involve the right to use coercion, whereas imperfect rights involve the right to request or petition.
} 
for Kant, wrongly assumes that by acquiring and mixing our labor with an object, we can acquire a secure property right in that object in the state of nature. But where, on such a picture, does the authorization to coerce others who also wish to use that object come from? There must be some justification for the permissibility of preventing others who wish to use your property that is compatible with their innate right to freedom if such coercion would be morally justified.

There are three gaps in the state of nature for Kant that make it the case that a government is required to perfect our property rights. ${ }^{52}$ The first I just mentioned - the fact that the unilateral judgment of one individual cannot justify limits on the freedom of other individuals. This includes restrictions on their freedom to use physical matter in the external world, including property that other people have a provisional right to. Second, we must have assurance from others that if we respect their property, they will do the same for us. Otherwise, we are not under an obligation to leave other people's property alone - respect for property rights must be reciprocal. And third, our property rights are indeterminate in the state of nature "with respect to quality as well as quantity." 53 According to Kant, the problem of indeterminacy is the "hardest to solve," and even if it is solved "through the original contract," acquisition remains provisional "unless this contract extends to the entire human race." 54 In Kant's discussions of property in The Metaphysics of Morals, he includes both individual property and the property of nations, in each case including rights to territory. The problems of assurance and determinacy, he holds, are subsumed under the problem of acquiring property, and the acquisition of

\footnotetext{
52 Ripstein, Force and Freedom: Kant's Legal and Political Philosophy, 24.

${ }^{53}$ Kant, The Metaphyiscs of Morals, 6:266, 53.

54 Ibid.
} 
property gives rise to the problem of how unilateral judgment and action of an individual that acquires an object or territory can, by their very discretion, possibly put others under an obligation to treat their property in particular ways. Kant's answer is that unilaterality cannot do so - political authority is required to make such interference with the freedom of others legitimate.

These gaps are not mere "inconveniences" of the state of nature in Locke's sense, ${ }^{55}$ but rather features that make the perfection of property rights contingent on the establishment of a constitutional political order. Three branches of government each serve the function of dealing with one of these gaps. The legislative branch solves the problem of unilateral judgment because it is capable of making laws from the standpoint of an "omnilateral will" which makes its determinations on behalf of the citizens as a collective body.$^{56}$ The executive branch solves the problem of assurance by enforcing the laws made by the legislative branch. And the problem of indeterminacy is solved by the judiciary, which applies the law to particular cases.

We have seen, then, that one of the features of human social life, for Kant, that requires a just domestic state to be secured is property, and property rights in particular. As Lea Ypi has recently discussed, the territories of states should be treated similarly. ${ }^{57}$ Any unilateral act of settlement or acquisition of territory, Kantian reasoning implies, is only provisional unless it is coupled with an obligation to enter into "universally

\footnotetext{
${ }^{55}$ John Locke, Second Treatise of Government, ed. C.B. Macpherson (Indianapolis: Hackett Publishing Company, 1690/1980), 54.

${ }^{56}$ Ripstein, Force and Freedom: Kant's Legal and Political Philosophy, 196.

${ }^{57}$ Lea Ypi, “A Permissive Theory of Territorial Rights," European Journal of Philosophy, 22, no. 2 (June 2014): 288-312.
} 
inclusive political relations." 58 And because individual property exists within the territorial confines of states, by the TDIP, individual property rights can only be secured when a just international order is present. ${ }^{59}$ Ypi points to a key passage ${ }^{60}$ where Kant emphasizes this moral dependence of domestic relations on international and cosmopolitan relations: "if the principle of outer freedom limited by law is lacking in any one of these three possible forms of rightful condition, the framework of all the others is unavoidably undetermined and must finally collapse."${ }^{\prime 61}$ Here again, the principal problem is that of political authority being needed to move from a unilateral act of acquisition or settlement to a justified state of affairs.

This view of the relationship between domestic property holdings and international justice not only accords with an interesting and plausible theory of property. It is also deeply intuitive, when spelled out in terms of our own entitlements. If the territory that I hold was recently stolen by my nation from another people and nothing has been done to address this fact, it seems indefensible for me to have the right to coerce the original owners if they attempt to recover their holdings. This situation wouldn't be made more acceptable by the mere fact that my nation was relatively just to insiders. And even in the case of historical injustices, there is something odd about claiming an unqualified right to continue using land that was stolen from indigenous peoples. It may also seem wrong to demand that innocent beneficiaries of such injustice give up all such

${ }^{58}$ Ibid., 19.

${ }^{59}$ Cf. Ypi, "A Permissive Theory of Territorial Rights."

${ }^{60} \mathrm{Ibid} ., 20$.

${ }^{61}$ Kant, The Metaphysics of Morals, 6:311, 89. 
benefits. ${ }^{62}$ What seems most appropriate is a solution that balances the fact of historical injustice with the state of things as they are, meaning that current people are not put in dire circumstances for the sake of righting the historical wrong. But in the absence of such a resolution, there is something very tempting about the thought that a nation such as the United States cannot, for instance, justifiably coerce descendants of indigenous peoples or other owners of historical lands to keep them out of its territory (Mexican people seeking to live in California or Texas, for instance). This accords well with the Kantian line of reasoning that unless the demands of justice between nations are satisfied, holdings within a nation that has perpetuated injustice against another are only provisional.

There are at least three more reasons why the TDIP holds. These also are not reasons that Kant himself affirmed, but they are compatible with Kantian deontology. First, there are relationships between citizens and non-citizens of a state which make it the case that the state's treating the non-citizens justly along some dimensions is required for it to treat citizens justly. ${ }^{63}$ The clearest illustration of this fact can be given in terms of immigration policy. In the ethics of immigration literature, Michael Walzer ${ }^{64}$ and Christopher Heath Wellman ${ }^{65}$ have held that immigration policies that use race or ethnicity as selection criteria are not morally impermissible for societies to implement

\footnotetext{
62 Jeremy Waldron, “Superseding Historic Injustice," Ethics, 103, no. 1 (October 1992): 4-28.

${ }^{63}$ Matthew Lindauer, "External Relationships in Political Philosophy," Doctoral dissertation, Yale University, 2015. ${ }^{64}$ Walzer, Spheres of Justice: A Defense of Pluralism and Equality.

${ }^{65}$ Wellman seems to have changed his views on such policies over time. See Christopher Heath Wellman, "Immigration and Freedom of Association," Ethics, 119, no. 1 (October 2008): 109-141 at 139-141 and Phillip Cole and Christopher Heath Wellman, Debating the Ethics of Immigration: Is There a Right to Exclude? (New York: Oxford University Press, 2011) at 149-150.
} 
even if it is morally regrettable when societies do so. But in a diverse, modern liberal state, there will typically be at least some citizens who are present that are members of races and ethnicities that states would keep out. Such policies thus treat those insiders as "second-class citizens." 66 This doesn't show, of course, that a state cannot exclude persons who don't share the relevant qualities with citizens. Nor does it imply that the only reasons to treat outsiders respectfully as reducible to reasons of respect for citizens. However, when we see that similar reasoning extends to the gender, religion, and sexual orientations, the extent to which societies are constrained in how they treat non-citizens if they are to meet the demands of domestic justice clearly supports the TDIP. The principle of equal respect for members, a core demand of liberal domestic justice, ${ }^{67}$ requires the state not to implement policies that exclude or give less than equal treatment outsiders on the basis of such qualities in a wide-range of cases. ${ }^{68}$ Meeting the demands of domestic justice therefore requires treating non-citizens in ways that many, but not all, of us think are required by the demands of international justice. Given other preexisting "external relationships" that citizens are parties to, such as relationships with non-citizen family members, it may also be the case that states can only give sufficient weight to the interests of their citizens if they constrain their conduct towards these non-citizens living elsewhere. A law-governed external relationship with other states and their members is required by the external relationships of a liberal society's own citizens. Fully making

\footnotetext{
${ }^{66}$ Michael Blake, "Immigration," in A Companion to Applied Ethics, eds. R.G. Frey and Christopher Heath Wellman (Malden, MA: Blackwell Publishing, 2003), 224-237 at 233234.

${ }^{67}$ Elizabeth S. Anderson, "What is the Point of Equality?," Ethics, 109 (1999): 287-337; Ronald Dworkin, Taking Rights Seriously (Cambridge MA: Harvard University Press), 1977.

${ }^{68}$ Lindauer, "External Relationships in Political Philosophy."
} 
the case for this point is beyond the bounds of this chapter, but I have shown at least one way in which attention to the relationships of citizens of liberal societies provides support for the TDIP.

Second, the TDIP may be supported by considerations involving a liberal polity's integrity ${ }^{69}$ which make it the case that it must uphold standards of international justice to maintain its domestic justice commitments. By trading with dictators or engaging in unjust wars, liberal democracies act in ways that contradict the commitments that they are supposed to uphold domestically - the commitment to the view that dictatorship is not a legitimate form of government, that unjust aggression is wrong, and so on. In order to act in ways that are consistently with its own commitments at home, a liberal state must carry its moral commitments over to its interactions with outsiders. Hence, the tie between domestic and international justice put forward by the TDIP is also supported by considerations grounded in the notion of a liberal state's political integrity.

Lastly, the TDIP is supported by the fact that in order to take actions that promote domestic security, liberal states must be taken seriously in their efforts to promote international justice. To be viewed as legitimate arbiters of international peace, which benefits the domestic polity, a liberal democracy cannot engage in acts of aggression or wars fought for suspect premises. The possibility of securing the conditions of a domestically just society, across many domains, will require that liberal societies participate on the international stage in ways that engender mutual trust and reciprocity. To tackle the shared threats that societies face, not only in terms of military threats but also to coordinate action on issues such as climate change and the global nature of

\footnotetext{
${ }^{69}$ Shmuel Nili, "Liberal Integrity and Foreign Entanglement," American Political Science Review, 110 (2016): 148-159.
} 
disease epidemiology, liberal societies must be shown to be trustworthy to other nations. Hence their preventing threats to the domestic polity, and thereby the conditions of domestic justice, depend in part on meeting demands of justice in their interactions with other states.

The first, stability-based point that I raised in favor of the TDIP is, again, one that realists can concede. The fact that it is often in states' interests to seek international stability for the sake of promoting their own stability at home does not put pressure on the realist who is skeptical about the role of moral considerations in international relations. However, the four additional points raised in this section point to a stronger connection between domestic justice and international justice that put pressure on such skepticism. A state whose conduct on the international stage is not constrained by moral requirements threatens to jeopardize its domestic property (including territorial entitlements, to violate demands of domestic justice, to harm its own political integrity, and to lose its legitimacy in taking actions that are required to maintain a justice domestic order. Each of these points presuppose that morality must play an important role in international relations - the price of an unjust international order includes the inability to secure domestic justice and many of its morally desirable features.

\section{Conclusion}

In this chapter I have shown that two interlocking themes in Kantian moral and political philosophy can inform our understanding of the Kantian perspective on international relations. A Kantian view can give a central role to moral considerations in theorizing international relations while holding that this role involves solving practical problems that arise at the international level. Further, Kant's view that solving the 
problem of a domestically just state is contingent on solving the problem of law-governed relations among nations can be shown to generate plausible and challenging claims about the relationship between domestic and international justice. These claims put pressure on realist views that hold that moral considerations are generally unimportant in international relations. Insofar as such theorists do not wish to deny the relevance of moral considerations to domestic justice theory, which would be a significant cost and argumentative burden for them to take on, it seems that they must grant a significant role to moral considerations in international relations. It remains for later work to examine each of the two main themes presented in this chapter in greater detail. Nonetheless, I hope to have shown that there is significant further material in Kantian moral and political philosophy for theorists to draw on in advancing and defending Kantian views in international relations.

\section{References}

Ameriks, Karl. "On Two Non-Realist Interpretations of Kant's Ethics.” In Interpreting Kant's Critiques. Oxford: Oxford University Press, 2003: 263-282.

Anderson, Elizabeth S. "What is the Point of Equality?" Ethics 109 (1999): 287-337.

Aristotle. Nicomachean Ethics, Second Edition, translated by Terence Irwin. Indianapolis: Hackett Publishing Company, 350 B.C./1999.

Bagnoli, Carla. "Humanitarian Intervention as a Perfect Duty: A Kantian Argument." Nomos 47 (2004): 117-148.

Blake, Michael. "Immigration.” In A Companion to Applied Ethics, edited by R.G. Frey and Christopher Heath Wellman. Malden, MA: Blackwell Publishing, 2003: 224-237.

Bull, Hedley. The Anarchical Society: A Study of Order in World Politics. New York: Columbia University Press, 1977. 
Luigi, Caranti. "Kantian Peace and Liberal Peace: Three Concerns." Journal of Political Philosophy 24, no. 4 (2016): 446-469.

Cole, Phillip and Christopher Heath Wellman. Debating the Ethics of Immigration: Is There a Right to Exclude? New York: Oxford University Press, 2011.

Doyle, Michael W. "Kant, Liberal Legacies, and Foreign Affairs." Philosophy and Public Affairs 12, no. 3 (1983a): 205-235.

Doyle, Michael W. "Kant, Liberal Legacies, and Foreign Affairs." Philosophy and Public Affairs 12, no. 4 (1983b): 323-353.

Dworkin, Ronald. Taking Rights Seriously. Cambridge MA: Harvard University Press, 1977.

Gilabert, Pablo. "Kant and the Claims of the Poor." Philosophy and Phenomenological Research 81, no. 2 (September 2010): 382-418.

Hurrell, Andrew. "Kant and the Kantian Paradigm in International Relations." Review of International Studies 16, no. 3 (1990): 183-205.

Kagan, Shelly. "Kantianism for Consequentialists." In Immanuel Kant, Groundwork for the Metaphysics of Morals, translated by Allen W. Wood. New Haven: Yale University Press, 2002: 111-156.

Kant, Immanuel. "Idea for a Universal History with a Cosmopolitan Intent." In Immanuel Kant: Perpetual Peace and Other Essays, translated by Ted Humphrey. Indianapolis: Hackett Publishing Company, 1784/1983a: 29-40.

Kant, Immanuel. Groundwork of the Metaphysics of Morals, translated by Mary Gregor. Cambridge, UK: Cambridge University Press, 1785/1997.

Kant, Immanuel. "To Perpetual Peace: A Philosophical Sketch.” In Immanuel Kant: Perpetual Peace and Other Essays, translated by Ted Humphrey. Indianapolis: Hackett Publishing Company, 1795/1983b: 107-143.

Kant, Immanuel. The Metaphysics of Morals, translated by Mary Gregor. Cambridge, UK: Cambridge University Press, 1797/1996.

Korab-Karpowicz, W. Julian. "Political Realism in International Relations." In The Stanford Encyclopedia of Philosophy, Summer 2013 Edition, edited by Edward N. Zalta, URL $=<$ https://plato.stanford.edu/archives/sum2013/entries/realism-intl-relations/>.

Korsgaard, Christine. Sources of Normativity. Cambridge, UK: Cambridge University Press, 1996. 
Korsgaard, Christine. "Realism and Constructivism in Twentieth-Century Moral Philosophy." Journal of Philosophical Research. APA Centennial Supplement: Philosophy in America at the Turn of the Century (2003): 99-122.

Lindauer, Matthew. "External Relationships in Political Philosophy." Doctoral dissertation, Yale University, 2015.

Locke, John. Second Treatise of Government, edited by C.B. Macpherson. Indianapolis: Hackett Publishing Company, 1690/1980.

Milgram, Stanley. "Behavioral Study of Obedience." Journal of Abnormal and Social Psychology 67, no. 4 (1963):371-378.

Morgenthau, Hans J. Scientific Man Versus Power Politics. Chicago: Chicago University Press, 1946.

Nili, Shmuel. "Liberal Integrity and Foreign Entanglement." American Political Science Review, 110 (2016): 148-159.

Noel-Baker, Philip. The League of Nations at Work. London: Nisbet, 1926.

O’Neill, Onora. Bounds of Justice. Cambridge, UK: Cambridge University Press, 2000.

Onuf, Nicholas Greenwood. World of Our Making: Rules and Rule in Social Theory and International Relations. Columbia, SC: University of South Carolina Press, 1989.

Pinker, Steven. The Better Angels of Our Nature: Why Violence Has Declined. New York, NY: Viking Books, 2011.

Potter, Pitman. An Introduction to the Study of International Organization. New York: The Century Company, 1925.

Rawls, John. A Theory of Justice. Cambridge MA: Harvard University Press, 1971/rev. 1999.

Rawls, John. "Kantian Constructivism in Moral Theory," Journal of Philosophy 77, no. 9 (September 1980): 515-572.

Rawls, John. Political Liberalism. New York: Columbia University Press, 1993.

Rawls, John. The Law of Peoples. Cambridge, MA: Harvard University Press, 1999.

Ripstein, Arthur. Force and Freedom: Kant's Legal and Political Philosophy.

Cambridge, MA: Harvard University Press, 2009. 
Rousseau, Jean-Jacques. The Social Contract, Or Principles of Political Right, translated by G.D. H Cole, 1762, public domain.

Shotwell, James T. "Plans and Protocols to End War." International Conciliation 208 (1925).

Street, Sharon. "Coming to Terms with Contingency: Humean Constructivism about Practical Reason." In Constructivism in Practical Philosophy, edited by Jimmy Lenman and Yonatan Shemmer. Oxford: Oxford University Press, 2012.

Waldron, Jeremy. "Superseding Historic Injustice." Ethics 103, no. 1 (October 1992): 428.

Waltz, Kenneth. Theory of International Politics. Boston, MA: McGraw-Hill, 1979.

Walzer, Michael. Spheres of Justice: A Defense of Pluralism and Equality. New York: Basic Books, 1983.

Wellman, Christopher Heath. "Immigration and Freedom of Association." Ethics 119, no. 1 (October 2008): 109-141.

Wendt, Alexander. "Anarchy is what States Make of it: the Social Construction of Power Politics.” International Organization 46, no. 2 (Spring 1992): 391-425.

Wilson, Peter. "Idealism in International Relations." In Encyclopedia of Power, edited by Keith Dowding. Thousand Oaks: Sage Publications, 2011, 332-333.

Wood, Allen. Kant's Ethical Thought. Cambridge, UK: Cambridge University Press, 1999.

Ypi, Lea. "A Permissive Theory of Territorial Rights." European Journal of Philosophy 22, no. 2 (June 2014): 288-312.

Zimmern, Alfred. The League of Nations and the Rule of Law, 1918-1935. London: Macmillan, 1936. 